\title{
Relationship between obesity and musculoskeletal disorders: A scope review protocol
}

\author{
Relação entre obesidade e distúrbios musculoesqueléticos: Protocolo de revisão de escopo \\ Relación entre obesidad y trastornos musculoesqueléticos: Protocolo de revisión del alcance
}

Received: 05/18/2021 | Reviewed: 05/27/2021 | Accept: 07/01/2021 | Published: 14/07/2021

Lucas Marques Fortunato

ORCID: https://orcid.org/0000-0001-6704-3126 Universidade Federal do Paraná, Brasil

E-mail: lucasmarquesfortunato@gmail.com

Tatielly Kruk

ORCID: https://orcid.org/0000-0002-7913-3273 Universidade Federal do Paraná, Brasil E-mail: tatiellykruk@gmail.com

Emilton Lima Júnior

ORCID: https://orcid.org/0000-0002-6887-9387 Universidade Federal do Paraná, Brasil E-mail: emilton.doc@gmail.com

\begin{abstract}
Obesity is considered a public health problem and the review of the scientific literature allows the observation of several changes in the musculoskeletal system associated with this disease. The objective of this study is to describe the relationship between these changes in obese children and adults. This article is a scope review protocol, a study methodology based on the structure described by Arksey and O'Malley. The study protocol followed the recommendations from the Preferred Reporting Items for Systematic reviews and Meta-Analyzes extension for Scoping Reviews (PRISMA-ScR) Checklis. It will be conducted in five stages: a) elaboration of the research question; b) identification of relevant studies; c) selection of studies; d) data extraction; e) summary of the results. The study aims to correlate musculoskeletal disorders in obesity, in different stages of bone maturation, which are less studied, in order to provide scientific evidence to health care professionals involved in the multidisciplinary treatment of this chronic disease.
\end{abstract}

Keywords: Obesity; Musculoskeletal disorders; Locomotor system; Scope review.

\section{Resumo}

A obesidade é considerada um problema de saúde pública e a revisão da literatura científica possibilita a observação de diversas alterações do sistema musculoesquelético associadas à doença. O objetivo do estudo é descrever a relação entre essas alterações em crianças e adultos obesos.Este artigo é um protocolo de revisão de escopo, uma metodologia de estudo baseada na estrutura descrita por Arksey e O’Malley, que segue as recomendações do Preferred Reporting Items for Systematic reviews and Meta-Analyses extension for Scoping Reviews (PRISMA-ScR) Checklist. Será realizado em cinco etapas: a) elaboração da questão da pesquisa; b) identificação dos estudos relevantes; c) seleção dos estudos; d) extração dos dados; e) síntese dos resultados. O estudo visa correlacionar os distúrbios musculoesquléticos na obesidade, em diferentes fases de maturação óssea, que são poucos estudados, a fim de agregar evidências científicas para profissionais da saúde, evolvidos no tratamento multidisciplinar desta doença crônica.

Palavras-chave: Obesidade; Distúrbios musculoesqueléticos; Aparelho locomotor; Revisão de escopo.

\begin{abstract}
Resumen
La obesidad se considera un problema de salud pública y la revisión de la literatura científica permite observar varios cambios en el sistema musculoesquelético asociados a la enfermedad. El objetivo del estudio es describir la relación entre estos cambios en niños y adultos obesos. Este artículo es un protocolo de revisión de alcance, una metodología de estudio basada en el marco descrito por Arksey y O'Malley, que sigue las recomendaciones de 'Preferred Reporting Items' para la extensión de revisiones sistemáticas y metaanálisis para revisiones de alcance (PRISMA-ScR). Se llevará a cabo en cinco etapas: a) elaboración de la pregunta de investigación; b) identificación de estudios relevantes; c) selección de estudios; d) extracción de datos; e) síntesis de los resultados. El estudio tiene como objetivo correlacionar los trastornos musculoesqueléticos en la obesidad, en diferentes etapas de maduración ósea, que son pocos estudiados, con el fin de sumar evidencia científica a los profesionales de la salud, involucrados en el tratamiento multidisciplinar de esta enfermedad crónica.
\end{abstract}

Palabras clave: Obesidad; Trastornos musculoesqueléticos; Aparato locomotor, Revisión del alcance. 


\section{Introduction}

Obesity is becoming a worldwide challenge given the growing number of individuals with this disease (Aaseth et al, 2019). The incidence has increased in recent decades and obesity has become a major public health problem (Castro et al, 2017; Calenzani et al., 2018; Malik et al, 2018; Shan et al., 2019).

Besides the metabolic complications observed in individuals with obesity, orthopedic problems can also be evidenced and these are less studied (Adebimpe, 2019). Increased Body Mass Index (BMI) has been identified as a risk factor for musculoskeletal symptoms (Malik et al, 2018).

Disorders of the locomotor system can lead to a range of health problems, from pain, discomfort and postural changes, to degenerative diseases, depending on the phase of bone maturation that the individual is at. These health problems may lead to increased disability and low quality of life (Berry et al, 2010; Brady et al., 2015; Lehnert et al., 2013).

Despite the limited scientific evidence available on the subject, the review of the scientific literature has shown several changes in the musculoskeletal system in different phases of bone growth, showing the importance of early therapeutic interventions based on changes in lifestyle and physical activity (Bliddal et al, 2016)

A systematic review published in 2019 addressed the effects of excess weight and the damage to the ostemioarticular system. The authors correlated this outcome with the biomechanical characteristics of the gait in children and adolescents (Molina-Garcia, et al, 2019).

This review approaches obesity as a condition that not only modifies the biomechanical functionality of the locomotor system in children and adolescents but alters the morphology of musculoskeletal structures, leading to orthopaedic diseases in the adult population, as well as in children and adolescents, as studied in the above-mentioned review.

\section{Methods}

This scope review will be based on the research study method described formerly by Arksey and O'Malley. Methodological improvements were subsequently made by Levac et al and the Joanna Briggs Institute (Peters et al., 2017; Tricco et al, 2018). This research study will be conducted in five steps, described below. These steps were previously published in other scope review protocols (Bolorino, et al, 2020; Kogien et al, 2020; Izu et al, 2020; Mazon et al, 2021; Paiva et al, 2021; Souza et al, 2021, Szpalher et al, 2021).

Step 1: Designing the research question

The PICO strategy, which consists of: P (patient or population), I (intervention or indicator), C (comparison or control) and $\mathrm{O}$ (outcome) will be used. In the context of this study, it will be applied as follows: P (individuals, both men and women, without distinction of race or age limit, with a BMI greater than $30 \mathrm{~kg} / \mathrm{m}^{2}$ ), I (validated methods of assessment to investigate changes in the musculoskeletal system), C (comparison between individuals with normal weight and/or overweight), and $\mathrm{O}$ (musculoskeletal disorders).

Therefore, the research question for this review is: "What are the musculoskeletal disorders of the locomotor system, that are secondary to obesity?".

\section{Step 2: Identification of relevant studies}

The selection of the descriptors used in the review process was conducted by consulting the Health Sciences Descriptors (DECs), which were subsequently combined with the boolean operators 'AND' and 'OR', generating a specific search strategy for each selected database (Table 1). 
Table 1 - Descriptors and boolean operators of search strategies.

\begin{tabular}{|l|l|}
\hline Data base & Search syntax \\
\hline Lilacs and Scielo & $\begin{array}{l}\text { ("postural disorders" OR "alteração de postura" OR "musculoskeletal } \\
\text { disorders" OR "Musculoskeletal Diseases" OR "doenças muscoloesqueleticas" } \\
\text { OR "alterações ortopedicas" OR "orthopedic alterations" OR "orthopedic } \\
\text { change") AND (obesidade OR Obesity OR Overweight OR sobrepeso) }\end{array}$ \\
\hline PubMed & $\begin{array}{l}\text { ("musculoskeletal disorders"[All Fields] OR "Musculoskeletal Diseases"[All } \\
\text { Fields] OR "orthopedic alterations"[All Fields] OR "orthopedic change"[All } \\
\text { Fields]) AND ("obesity"[MeSH Terms] OR "obesity"[All Fields]) OR } \\
\text { ("overweight"[MeSH Terms] OR "overweight"[All Fields])) }\end{array}$ \\
\hline Scopus and Web of Science & $\begin{array}{l}\text { ("musculoskeletal disorders" OR "Musculoskeletal Diseases" OR "orthopedic } \\
\text { alterations" OR "orthopedic change") AND (Obesity OR Overweight) }\end{array}$ \\
\hline
\end{tabular}

Source: Authors (2021).

Step 3: Study selection

All stages of the selection process will be conducted by two independent researchers (LMF/TK), and the discrepancies will be decided by consensus. In the first step of the selection, potential studies identified through the database search will be inserted in the web-based systematic review software package "Covidence" (Veritas Health Innovation), in order to detect duplicate articles. After excluding duplicates from the database, titles and abstracts will be examined to identify potential articles for inclusion. In the second step, the full article text will be examined for final inclusion/exclusion decision.

For the selection of articles, inclusion and exclusion criteria will be established. The inclusion criteria are: a) studies with humans (with no distinction of race, sex and age), regardless of the sample size, b) sample with a BMI greater than 30 $\mathrm{Kg} / \mathrm{m} 2$ for adults and equal to or greater than the $85^{\text {th }}$ and $95^{\text {th }}$ percentile for age and sex respectively for children and adolescents, c) articles published in Portuguese, English and Spanish, d) articles with observational design, e) articles that used valid methods of assessment. The exclusion criteria are: a) duplicated articles, b) non-indexed articles, c) special populations, such as those with movement disorders or pain, d) meeting summaries, editorials, letters to the editor, and reviews. Functionality assessments of the locomotor system due to musculoskeletal disorders are beyond the scope of this review and will not be included.

Step 4: Data extraction

Data will be extracted in a standardized manner, according to author and year of publication, type of study, journal where it was published, title and purpose of the study. Subsequently, the assessment methods and the outcomes will be obtained.

\section{Step 5: Summary of the results}

The flow diagram of the meta-analysis will be used in the studies included in this review and the entire selection process and will follow the checklist recommendations adapted from the Preferred Reporting Items for Systematic reviews and MetaAnalyses extension for Scoping Reviews (PRISMA-ScR) (Peters, et al., 2015).

\section{Results Report}

The relationship between obesity and musculoskeletal diseases that will be identified in this scope review will be published in an open access scientific journal.

\section{Final Considerations}

Excess weight is the main cause of musculoskeletal discomfort, consequently leading to orthopaedic disorders of the locomotor system. The main contribution of this study is to advance the knowledge for health care professionals about these disorders that are secondary to obesity, which are less frequently studied. 
Additionally, it will contribute with scientific evidence by elucidating the various ways in which these disorders may manifest in different stages of bone maturation, corroborating the diagnosis and musculoskeletal rehabilitation of the individual with excess weight.

\section{Conflict of interest}

The authors declare that they have no conflict of interest.

\section{Acknowledgments}

To the Coordination for the Improvement of Higher Education Personnel (CAPES), for funding this research.

\section{References}

Aaseth J., Roer G. E., Lien L., Bjorklund G. (2019). Is there a relationship between PTSD and complicated obesity? A review of the literature. Biomed Pharmacother. 11(7):108-134.

Adebimpe W. O. (2019). Prevalence and knowledge of risk factors of childhood obesity among school-going children in Osogbo, south-western Nigeria. Malawi Med J. 31(1):19-24.

Berry P. A. et al. (2010). The relationship between body composition and structural changes at the knee. Rheumatology. 49(12):2362-9.

Bliddal M. et al. (2016). Association of Pre-Pregnancy Body Mass Index, Pregnancy-Related Weight Changes, and Parity With the Risk of Developing Degenerative Musculoskeletal Conditions. Arthritis \& Rheumatology. 68(5):1156-64.

Bolorino N. et al. (2021). Performance by Community Health Agents on leprosy control actions: a scoping review protocol. Research, Society and Development. 9(9).: 1-9.

Brady S. R. E. et al. (2015). Body composition is associated with multisite lower body musculoskeletal pain in a community-based study. The Journal of Pain . 16(8):700-706.

Castro G. G. (2017). Sobrepeso e obesidade infantil: fatores predisponentes para alterações ortopédicas. Fisioter Brasil. 18(4):426-32.

Calenzani G., Santos F. F., Wittmer V. L., Freitas G. K. F., Paro F. M. (2017). Prevalence Of Musculoskeletal Symptoms In Obeses Patientes Candidates For Bariatric Sugery And Its Impact On Health Related Quality Of Life. Arch. Endocrinol. Metab. 61(4):319-325.

Izu M., Silnino Z. R., Santos L. M., Balbino C. M. (2020). Cuidados de enfermagem de pacientes submetuidos a transplantes de células tronco hematopoiéticas: Protocolo de revisão de escopo. Research, Society and Development. 9(7): 1-6.

Kogien M., Marcon S. R., Oliveira A. F., DeLeite V. F., Modena C. F., Nascimento F. C. S. (2020). Associated factors to suicidal behavior among graduate students - scoping review protocol. Research, Society and Development. 9(10):1-9.

Lehnert T., Sonntag D., Konnopka A., Riedel-Heller S., Konig, H. H. (2013). Economic Costs Of Overweight And Obesity. Clinical Endocrinology \& Metabolism. 27(2):105-115.

Malik K. M., Beckeriy R., Imani F. (2018). Musculoskeletal disorders a universal source of pain and disability misunderstood and mismanaged: A critical analysis Based on the U.S. model of care. Anesth Pain Med. 8(6).

Mazon L. M., Siewert J. S., Duarte V. M., Fernandes E., Dumke G. O. (2021). Therapeutic effects of auriculotherapy on anxiety syndromes among adolescents: A scoping review protocol. Research, Society and Development. 10(5).

Molina-Garcia P. et al. (2019). A systematic review on biomechanical characteristics of walking in children and adolescents with overweight/obesity: Possible implications for the development of musculoskeletal disorders. Obes Rev. 3(20):1033-44.

Paiva C. C. N., Santos D. L., Cotrim Junior D. F., Cabral L. M., Cabral S. C., Esparis I. M. (2021). The Unified Health System and its challenges in implementing sexual and reproductive health care for the LGBTQIA + population in Brazil: Scoping review protocol. Research, Society and Development. 10(3): 1-12.

Peters M. D. J., Godfrey C., McInerney P., Baldini S. C., Khalil H., Paker D. (2017). Joanna Briggs Institute Reviewer's Manual. In: Aromataris E., Munn Z. Joanna Briggs Institute Reviewer's Manual.

Adelaide: Joanna Briggs Institute, 2017. https://reviewersmanual.joannabriggs.org/.

Shan M. B. A., Guo Y., \& Zou Y. (2019). A novel insight into predicting overweight/obesity in undergraduates. Medicine. 98(21):34-46.

Souza, V. L. et al. (2021). Conceptual frameworks used in the evaluation of Telehealth initiatives: A scoping review protocol. Research, Society and Development. 10(6): 1-12.

Szpalher A. S. et al. (2021). Assessment and diagnosis of insomnia for clinical and research practice: a scoping review protocol. Research, Society and Development. 10(4): 1-10.

Tricco A. C et al. (2018). PRISMA extension for scoping reviews (PRISMA-ScR): checklist and explanation. The PRISMA-ScR Statement. Ann Intern Med. 169(7):467-73. 